\title{
Knowledge and authentic development: the value of Political Theory to Development Studies
}

\section{Conhecimento e desenvolvimento autêntico: o valor da Teoria Política para os Estudos de Desenvolvimento}

\author{
Bernard Nwosu, University of Nigeria \\ Okechukwu Ibeanu, University of Nigeria
}

\begin{abstract}
Development studies are a beneficiary of knowledge resources from several disciplines including political theory's analytic and prescriptive input. The dominant background of political theory and other disciplinary contributions to development studies is the liberal thought. Liberal theses on development seem to presume that development only makes meaning from such perspective. However, tensions arise in knowledge claims between the neoclassical liberals and alternative liberal scholars especially the neo-Keynesian on the one hand and more radical neo-Marxist thoughts on the other hand. The tension is centrally concerned with contention between the market sovereignty of the neoclassicals and state interventionism of the Keynesian and neo Marxist radical thoughts. These contentions draw in the role of the State in development and hence, create an opening for political theory's intervention. This paper establishes the nexus of political theory and development studies by focusing its subject matter, methodology and social commitments. The main claim of the work is that the dominant liberal ideas on development fail to capture the realities of all societies, yet the alternative frameworks, despite their promise, have yet to elaborate their tenets to capture the nuances of developing societies in Africa. Accordingly, the decisive intervention in defining the roles of both citizens and state for a development based on constructivist understanding of society is a necessary role of political theory in development studies.
\end{abstract}

Keywords-Development Studies, Political Theory, Methodology, Social Commitment.

Resumo-Os estudos de desenvolvimento são beneficiados pelos recursos de conhecimento de várias disciplinas, incluindo os inputs analíticos e prescritivos da teoria política. O pano de fundo dominante da teoria política e outras contribuições disciplinares aos estudos de desenvolvimento é o pensamento liberal. As teses liberais sobre desenvolvimento aparentam pressupor que o desenvolvimento apenas faz sentido a partir dessa perspetiva. No entanto, as tensões surgem sob a forma de procura de conhecimento entre os liberais neoclássicos e estudiosos liberais alternativos, especialmente o neokeynesiano, por um lado, e os pensamentos neo-marxistas mais radicais, por outro lado. A tensão está centralmente relacionada com a disputa entre a soberania de mercado dos neoclássicos e o intervencionismo estatal dos pensamentos radicais keynesianos e neo-marxistas. Estas disputas atraem o papel do Estado em desenvolvimento e, portanto, criam uma abertura para a intervenção da teoria política. Este artigo estabelece o nexo da teoria política e estudos de desenvolvimento ao focar-se na temática em questão, na metodologia e em compromissos sociais. A principal reivindicação do artigo é que as ideias liberais dominantes sobre o desenvolvimento falham em captar as realidades de todas as sociedades, ainda que as estruturas alternativas, apesar das suas promessas, ainda não tenham elaborado os seus princípios para capturar as nuances das sociedades em desenvolvimento em África. Consequentemente, a intervenção decisiva na definição dos papeis dos cidadãos e do Estado para um desenvolvimento baseado na compreensão construtivista da sociedade é um papel necessário da teoria política nos estudos de desenvolvimento.

Palavras-Chave-Estudos de Desenvolvimento, Teoria Política, Metodologia, Compromisso Social.

Submitted-14-04-2016. Accepted-02-06-2017. 


\section{Politics and Political Theory}

$\mathrm{P}$ OLITICS surrounds our lives more than we often imagine. Beyond the more common attitude of associating the political with governmental, its realms stretches from the remote subjects of nutrition of infants, health of the aged, quality and quantity of farm yields, extraction of underground minerals to decisions in the parliaments, constitutional matters and more. Generally speaking, politics provides a context for organizing public decisions. In that sense, the nutrition of infants which appears much like a private matter of families is pretty much a public policy matter in which case the cost of baby foods could be exempted from taxation to reduce cost and increase affordability just like a policy of either superannuation for the aged or medical care subsidy can enhance access to medical care. Agricultural policies that target food sufficiency in developing countries could evolve measures to support research and spread of improved crops and perhaps subsidies of farm input. Accordingly, politics and political science are centered on value allocation. As a subject, Political science studies interactions in the context of politics and organizes its intellectual engagement with political practice around systematic explanation. The main tool for this systematized explanation is Political Theory.

Political theory is within the rubric of social science theories. Like all theories, it purports to explain reality and is constituted by set of tested or testable propositions. The case Political of Theory is slightly different in that it not only accepts and applies the method of hypothesis testing but also addresses conceptual, normative and evaluative questions such as the meaning of democracy, how we ought to organize our political system and how to evaluate the desirability of policies (List and Valentini 2014). The terrestrial sciences like Physics and Mathematics possess a more confident bearing in matters of theory because of the grand nature of their propositions and tight analytic precision when compared to social

- Bernard Nwosu and Okechukwu Ibeanu, Institute for Development Studies, University of Nigeria.

E-mail:ben.nwosu@unn.edu.ng

DOI:http://dx.doi.org/10.21814/perspectivas.79 theories. Nonetheless, social phenomena can still be explained around certain general principles or at least meta-narratives. For instance, cognitive dissonance might come handy in explaining the conformity of drivers who learn to use seat belts because of fear that they might face sanctions of the law. Similarly, a range of theories of rational choices explain not only economic behaviour but also voter choices which is a political phenomenon. In this sense, the general idea of theory which applies in the normal science also applies in the science of society. This essence of theory is captured in List and Valentini's $(2014,12)$ definition that theory is a set of set of statements - propositions expressed in language which is a candidate for playing some theoretical practical role and which is ideally representable as the set of all implications of the underlying principles.

The aim of theory according to Laudan is "to provide satisfactory answers to important problems in the field which they are a part." (cited in Parayil 1990, 48). This also applies to Political theory. Our purpose here is to explore how Political theory bears relevance to development studies while it performs the function of explaining political phenomena. To specifically explore the value of political theory to development studies, we focus on how it connects with the subject matter, methodology and social commitment of development studies.

\section{Development Studies: Meaning and Genealogy}

The genealogical development of the field of development studies began with its birth and accommodation as a research tradition within development economics from which it came under the influence of the dominant neo classical methodology from Economics. Following series of transformation, the discipline's current approach is to draw from various subject areas such as Economics, Political Science, Sociology and Anthropology.

The formal origin of development studies goes back to a post-World War II development in which many economists began to question the adequacy of neoclassical theories, particularly their application as relevant tools for the analysis of the Third world (Parayil 1990). Parayil's narrative 
on the history of the discipline informs that it began as a separate sub-discipline in development economics. Development economics as a specialty in the broader discipline of economics came under stress due to division in the field occasioned by structural and neoclassical scholars. Structuralists favour state interventionism or dirigisme as an approach for driving development as contained in Keynesian modes of thought (see Keynes 1926). Neo-classical scholars insist on the deterministic power of price mechanism (see Lal 1983). Incidentally, the neoclassical methodological and ideological tradition has emerged as the dominant one and exerts a strong hold on the major global development institutions such as the World Bank and the IMF both of which have significant influence on the policies of developing countries.

Originally, the methodological focus of Development Economics was inward looking and narrowly focused on economics and was not amenable to multi-disciplinary or cross disciplinary approach. Nonetheless, a few of the founders of Development Studies carved out the status of the new discipline as a separate research area. This group of minority economists defined development more broadly to include the social and economic dimensions and recognized the importance of issues of equality, transcended individualistic focus. Also, they reckoned with the relevance of communitarian patterns of work, the fostering of ecological balance between people and nature, cultivation of psychological balance between the material and the spiritual and the promotion of cultural and institutional diversity rather than the remaking of the Third World to replicate advanced capitalist societies. With such a break in tradition of research, the subject matter and fundamental principles of neoclassical economics came under serious attack. As a result, Development Studies emerged as a separate discipline, and sought to overcome neoclassical orthodoxy. Nevertheless, it did not totally escape the retention of some of the old commitments of "development economics." Other disciplines interested in issues related to the development of the Third World began to influence the thinking in development (see Parayil 1990).

It was the opening for other disciplines on the subject matter of development that created the entry point for Political Science into the Development Studies at least in the formal sense of it. But it is needful to note that prior to formal access of Political science into Development Studies, the discipline had a very old history of engagement with development discourse and this goes as far back as the classical works of Plato, Aristotle, Thomas Hobbes, John Locke and many more. Indeed, what came to be Economics was earlier known as political economy. The movement to disconnect the word 'political' from the subject was part of the transformations of economics that goes back to the entry of mathematicians like Alfred Marshal into the field of Economics and their commitment to constructing a discipline of 'economic science' in which knowledge search is guided by mathematical models and the claims of testing "value-free" hypothesis. This development surely made its contribution to Economics. However, its approach of seeking answers to economic problems mostly by resort to equations and models produced results that ignore some fundamental elements which also frame the trajectory of material progress of society. Culture and values for instance are important factors in development. Kwon (2011), Ntibagiriwa (2009), Fernandez (2010), Harrison (2000) among several others are in accord that culture matters and is fundamental to development.

Although several arguments including those from the mainstream social science lend voice to the importance of culture to development, the dominant view has the inclination to condemn cultures that do not align with a particular social project in addition to reification of practices that further the preferred social project. Inglehart (2000), Granato, Inglehart and Leblang (1996), Stockwell and Laidlaw (1981), among other works in sociology of development are of the view that if a culture does not provide conditions that nurture a capitalist market society, then development is unlikely to happen. For this group of writers, nothing else but growth of market and conditions that nurture capitalism and all its structures constitute development. This group writers especially Inglehart and others with Political science background apply the theoretical paraphernalia of the discipline for growing the development discourse at least as it affects politics. For instance, after 
providing the contrasting sets of values associated with traditional values of pre-modern societies and with sercular rational values of the modern ones, he argues that the process of modernization tends to bring cultural changes conducive to democracy (see Inglehart 2000). The tools, concept and ideology of liberal Political science of Inglehart's inclination share relationship with the tools of other mainstream social science subjects like Economics, Sociology, Anthropology and others. The overarching interest of this strand of scholarship is to promote a variant of modernization which is at the heart of their intellectual engagement. They also share a social commitment in the defense of liberalism.

\section{Modernization: The Subject Matter of Development Studies and Political Theory}

Development studies draw significantly from the subject areas of Economics, Sociology and Political science but equally supplemented by a range of other disciplines. The reason for the establishment of Development Studies in its early post World War II history was to explore how to stimulate the processes of transformation that would enable the underdeveloped parts of the world become like the developed countries of the West. In a sense, it is concerned with how to transcend the developmental stage of the subjects of development to higher ones. One broad concept around which development discourses is organized in the major disciplines concerned with development is modernization. Modernization can be understood as a process of transformation from traditional to modern society and involves changes in the major facets of society that centrally include the political, social and economic levels of structure. These transformations in themselves are not bad, but the problematique around modernization is that several scholarships on it project the western experience as the common standard that must be reproduced in all societies.

Ake (1982) qualified the tendency in social science scholarship to extend the patterns development of the Western societies as the standard process which every other society must undergo as Eurocentric teleologism, an attitude which portrays the social science as imperialistic. To illustrate Ake's argument here, Weber claimed that the protestant ethic is the main cultural force of capitalist development but noted that the Confucian ethics could not promote the rational instrumentalism necessary for the advancement of material development (Weber 1992). Implicit in that Weberian thesis is a presumption of a higher and lower ethics in which the western protestant ethic is at a higher continuum of evolution. To illustrate further, in Rostow's (1960) contribution to modernization, he argued that societies develop in five stages beginning with the traditional stage, pre-take off stage; take off stage, drive to maturity and high mass consumption (the stage of western societies). The model towards which every society is supposed to move is the mass consumption stage.

Contemporary language of Economics are still majorly couched in terms that reflect the need to move towards the Western model. In fact the major explanation for economic problems in developing countries is non transformation to behavioural forms that support western type development. In more recent times, leading economic theories are grounded on neoliberalization which is another form of expression for transformation to western market society. The works of Friedman (1962), De Soto (1993; 2000) Acemoglu and Robinson (2013) all are united in expressing a project that illuminates the market order and prescribe such order as the only viable one to development. However, China which is currently the second largest global economy has an approach to modernization which according to Fangjun (2009) has to do with drawing on the useful and discarding the unfit. This suggests that no one story of modernization holds the recipe for the development of all societies.

Sociological contributions to the theme of development especially from the dominant mainstream viewpoint are represented by the works of Emile Durkheim which suggests that pre-modern societies are characterized by mechanical solidarity while modern society is characterized by organic solidarity. Such characterization is similar to an earlier one made by Toennies who sees that societal development proceeds from Gemeinschaft to Gazelleschaft characteristics. While Gemeinschaft society is a traditional and status-bound 
order in which life chances are determined by circumstances of birth and lack of disposition to behave according to market norms, Gazelleschaft society is one in which the tendency to act according to market norms is high, individual effort influence life chances and orientations are specific rather than diffuse. Further sociological contributions to development theory include the works of Talcott Parson who worked out dichotomous action orientations for undeveloped and developed modern societies. In those five action orientations, affectivity would apply to the pre-modern society as affective neutrality defines the modern society. Also, collective orientation versus selforientation, diffuseness versus specificity, ascription versus achievement and particularism versus universalism respectively apply to undeveloped pre-modern societies and developed modern ones (cf. Ake 1982).

The point of these development sociologies is that the progress of societies is dependent on the adoption of measures and value system that move them towards the modern societies which are posed as superior to traditional ones. In other words, sociological modernization is taken to be essential for development. More recent works on sociology of development are also stuck in the reification of the so called modern societies and their values. For instance, Stockwell and Laidlaw (1981) applied the old logic of modernization to analyze developing societies. What they called societal approach to development identified three major problems of development namely economic, demographic and socio-cultural problems. At the economic level, they identified the lack of natural resources, low technology base and primitive modes of production, high rates of illiteracy, poor nutrition, ill-health and lack of technical skills. The points the authors identified almost entirely replicates the characteristics put forward by Maines (1956) and Leibenstein (1956) (Both cited in Ake 1982) about underdeveloped societies. Taking on demography, Stockwell and Laidlaw claim that less developed countries have a high rate of population growth due to social structures and practices that support and encourage population growth. The consequence of demographic expansion according to the authors is pressure on the national income for the purpose of providing basic necessities at the cost of more productive application. In socio-cultural terms, the less developed societies are found to be traditional and characterized by rigid stratification systems together with values that emphasize the group rather than individual and a conservative orientation that glorifies the past and insists on their preservation instead of change.

Continuing, the authors created a schema of interaction between the environment, social structure, culture and polity (ESCUP) and suggested that the reproductive practices of any society are sustained by institutions and norms of ESCUP. Connected to this claim is that the Fertility Behaviour (FB) of each society is the result of primary ESCUP institutions operating through Reproductive Practices (REPP). Also the Economic Values (EVA) and practices of any society are derived from the primary institutions of ESCUP. Equally in any given society, the Economic Behaviour is the result of primary ESCUP institutions operating through the dominant Economic Values and Attitudes (EVA). Using these propositions, the authors' main claims were that the ESCUP institutions of traditional societies their Reproductive Practices, Fertility Behaviour, Economic Values and Attitudes and Economic Behaviour are behind when compared to modern practices that could lead to development. The environment of scarcity in developing societies is seen to be why they approach issues of access to resources with practices of inequality, their social structure celebrates large extended family which inhibits modernization due to emphasis on mutual obligations for support contrary to individualism that is better suited to individual interests. The authors also concluded that cultures of less developed societies do not promote the kind of ethics that Weber wrote of in the Protestantism (see Weber 1992) and therefore does not support economic development. Also in terms of their polity, their governments have soft institutions that cannot enforce rights which are necessary for development. The exhortation of the authors is that for societies to develop, they must adopt institutions that foster modernization and capable of leading to property rights and market ethos. Not only that these theses reflect earlier modernization writings, some of its propositions 
are shibboleths that have been successfully challenged both in theory and practice. The massive economic progress in East Asia has compelled a reconsideration of an earlier faulty thesis that the Confucian ethics is not amenable to development like Weber's protestant ethics. Not only that the work ethics that draw from Confucian religion is found to support hard work, it is demonstrated to be part of the factors that drove development in the South East Asia (see Kwon 2011).

At the level of political theory, Ake (1982) demonstrates the modernization inclination of the dominant political science interpretations. One of the main postulates of the theory of political development in the leading works of Gabriel Almond and Lucian Pye is that "political development occurs to the extent the political system undergoes cultural secularization and structural differentiation" (Ake 1982, 139). Structural differentiation "is the process whereby roles change and become more specialized or whereby new types of roles are established or more autonomous..." (Ake 1982, 2425). The establishment of new roles and patterns of relationships in a government establishment (eg Ministry of education, the courts etc) illustrates structural differentiation. Cultural secularization is said to be "the process whereby men become increasingly rational, analytic and pragmatic in their action" (cited in Ake 1982, 18). Another important attribute of cultural secularization is a movement from diffuseness to specificity of orientations (cited in Ake 1982, 19). It is further seen as the process whereby traditional orientations and attitudes give way to more dynamic decisionmaking processes involving the gathering of information, evaluation of information, the laying out of alternative courses of action, the selection of a course of action from among these possible courses, and the means whereby one tests whether or not a given course of action is producing the consequences which were intended (cited in Ake 1982, 18-19).

What becomes clear in consideration to the above conceptualization of political development is that cultural secularization represents a movement towards modernity just like structural differentiation is a suggestion that increasing differentiation of roles and specialization in performing them represents a transcendence of the antecedent ways of getting things done to better modern ways. Structural differentiation as a concept reflects one of the pairs of Parsons (1951) pattern variables namely, diffuseness versus specificity in which specificity which supports differentiation and specialization is the desirable and higher characteristic in social pattern. In both Almond's theory of political development and Parson's sociology, they replay the metamorphosis of the Western society and tend to frame them as the logical process of development that should apply universally to every society. Not only that, when we bring into focus the sense of cultural secularization also described as becoming increasingly rational, analytic and pragmatic, the logical question that follows is the kind of pragmatism or rationality that is meant. Resolving such a question leads to a minefield of relativity of rationality since the terminology is susceptible to value judgment. For instance, Africa's Ubuntu philosophy gives emphasis to collective good as the framework of realizing private good. Thus, in the Ubuntu world view, collectivist orientation is considered rational and superior to individualist orientation in thinking about development of society (cf. Ntibagirirwa 2009). In this regard, if we think about turning the table of power relations and Africa is in a position to diffuse her own patterns of social relations, the obvious consequence would be a relegation of individualism to the background of collectivism. Incidentally, attitudes or ideas that diverge from liberal individualism do not count in favor of development in the considerations of Almond, Pye and some Western writers in the theory of political development. Hence their sense of rationality, pragmatism and analytical disposition are sign posts that lead to liberal individualist rational choice - a principle which underpins the political expression of liberalism in the form of liberal democracy.

More recent writings on political theory indicate that the dominant perspective on politics has not moved away from western modernization. Huntington's (1991) third wave democratization, Fukuyama's (1992) end of history among other works celebrate liberal democracy (not even democracy) as the logical end state to political development. In a more detailed theorizing of liberal democracy Schumpeter (1976) proposed an 
idea of democracy that confines the role of the people in a democracy to producing governments through election. To him, the democratic method is chiefly defined in terms of competitive struggle for power. In effect, participation is majorly about election. And once the electors appoint a body of executives, the business of decision making belongs to the executives. Schumpeterian theory of democracy which obscures the idea of peoples' power as the essence of democracy exercises a strong hold on liberal democracy scholars such that contemporary emphasis on political development is on elections. A society is therefore taken to be on the path of political development when it conducts elections and begins to replicate political structures similar to those of liberal democracies. Individual voter's rationality at the point of electing their representative is the heart of participation in liberal theory. Nwosu (2012) showed the hollowness of such emphasis in the case of Africa where pressures for democratization is diluted with limited focus on election. Authoritarian leaders in Africa have conducted phony elections to achieve external legitimacy while continuing to stifle conditions that could grow peoples' power and participation which are central to democracy. Drawing from Nwosu's idea, we argue that the present false imitation of liberal democracy in Africa and parts of the developing world has a basis on the theory around which political development is organized.

Considering the intervention of Political theory based on the above reviews, the political aspect of development studies tend to be committed to the advancement of liberal theories of development. It glosses over the need for constructivist remodeling of democratic governance based on the peculiarities of different societies. This assertion is not unmindful of radical theories in political science and other disciplines of social change but establishes an evident fact of the ascendancy of liberal individualism in political theory. Related to subject matter as a framework for understanding political theory's impact on Development studies is the methodology of the discipline.

\section{The Methodology of Development Studies and Political Theory}

In this section, we make a connection between Development Studies and political theory, even though the section on genealogy of development studies had drawn attention to this. As earlier mentioned, the origin of development studies as a research tradition in development economics influenced its earlier methodology. It was inward looking and refused to make recourse to other disciplines outside Economics in search of explanation for development issues. However radical critique of neoclassical modernization economics gradually paved way not only for the birth of a new research tradition, but also one which was open to insight from other subject areas. Thus the rise of development studies as an autonomous discipline went hand in hand with the emergence of multi-disciplinary approach and gradual progress to interdisciplinary and more rarely transdisciplinary approaches.

Multi-disciplinarity could be likened to a mural in which all objects within a large painting stand out clearly in their characteristics. More concretely, multi-disciplinarity implies that a particular development challenge may be addressed from a multi-disciplinary perspective with each of the participating discipline retaining its essential methodological approaches perhaps in a bid not to dilute either their autonomy or methodological purity. This especially happens between more quantitatively oriented social sciences and other disciplines. We may explain this tendency with a point which Pocock makes of interdisciplinary communication which is, "...nearly all methodological debate is reducible to the formula: you should not be doing your job, you should be doing mine" (cited in Frazer 2010). While Pocock addresses inter-disciplinarity, his remark bears even more on multi-disciplinarity in the sense that it permits little methodological flexibility between various participating disciplines in Development studies. Ultimately, multi-disciplinary methodology tends to present discordant voices in an orchestra that aspires for harmony. Where one subject matter is under interrogation each subject area retains its theoretical and methodological orientation. The behavioral transformation in the 
social sciences as Frazer (2010) suggests, worsens this situation because sometimes the normative theories hardly sit quite comfortably with the behavioral theories that claim to test value free propositions.

Beyond multi-disciplinary approaches is the inter-disciplinary method which is according to Sumner and Tribe (2008) is a step further towards integration wherein two or more disciplinary approaches concerned with the combination of disciplinary approaches within a research exercise. More than the multi-disciplinary approach, the interdisciplinary method lays background to the emergence of a higher form of methodological unity in transdisciplinarity. At this level, there are greater shared perspectives. More importantly, a sense of convergence begins to emerge at the level of theory. This last form is illustrated with the emergence of ethnography from Anthropology with insights from Anthropology, Philosophy, Sociology and other disciplines (see Sumner and Tribe 2008).

To sum it, the developmental stages of methodology of development studies is the movement through multi-disciplinarity and interdisciplinarity to transdisciplinarity. Transdisciplinarity is a point of methodological and theoretical unity. At this point, a new discipline or autonomous methodology which applies the combined insights of many constitutive disciplines dissolves into one framework of analysis. Choi and Pak (2006) described the three thus: multidisciplinarity draws on knowledge from different disciplines but stays within their boundaries. Interdisciplinarity analyzes, synthesizes and harmonizes links between disciplines into a coordinated and coherent whole. Transdisciplinarity integrates the disciplines and transcends their boundaries. The level of transdisciplinary approach re-echoes in Ake's (1982) proposal for a unified social science.

\section{The Social Commitment of Develop- ment Studies and Political Theory}

Following the dominant subject matter and methodology of Development Studies, it is not difficult to pin down its social commitment. Indeed at the very beginning of political science,

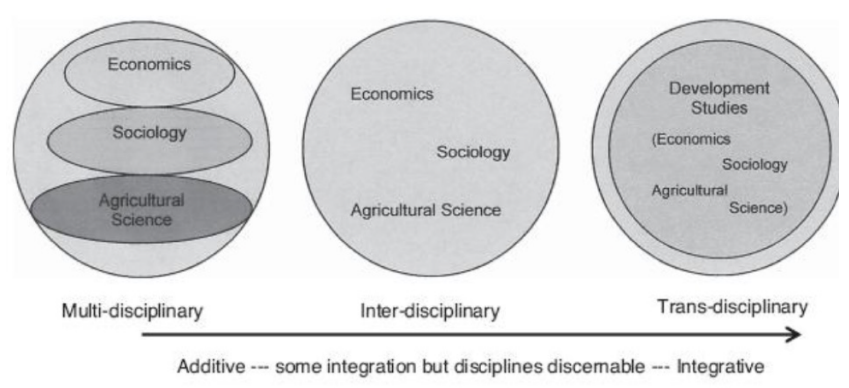

Source: Sumner and Tribe (2008)

it did not make any pretense about its commitment to the defense of liberalism. Much older disciplines like Economics and Sociology were earlier liberal oriented disciplines that actually facilitated the growth of capitalism. Political theory itself was not only within the household of philosophy but also grew from Sociology, History and Anthropology. Dwelling majorly on the work of Herbert Spencer, the contribution of English sociology to political theory was illuminated by Barnes (1921). For instance, Spencer is said to revive the contract doctrine to justify political authority. He also put forward a sociological statement of individualism in which the state was subordinated to the individual. Besides, Spencer correlated the state with society in general, in the attempt to estimate its position and roles in social processes. The liberal principles which are expressed in these contributions did not end as works of sociology or political theory; rather they were carried over to Development Studies which re-echoes the ideological commitments of its constitutive disciplines. More recently, economic discourses revolve around neoliberal economics. Indeed for some scholars creating a civil society is about reducing politics and freeing the market (see Edwards 2014, Fukuyama 2001). The same theoretical inclination bears strongly on a political theme like democracy in which there is a tendency to reduce the concept to a market phenomenon. Saltman, for instance argues that a faulty prevailing notion of democracy in recent times is that it is equal to "liberal capitalism" (see Wells, Slayton, and Scott 2002, 343).

Political development is still viewed as development in line with Western liberal democracy. This notion joins other notions of liberal indi- 
vidualism that are propagated in the dominant Sociology, Economics, Anthropology and other disciplines in constructing the hegemony of liberalism. The contribution of Political theory here is the generation of meta-narratives that reinforce liberal assumptions about the political side of structure so as to provide support to the economic and other aspects of society. Thus, the ultimate role of political theory is articulating and defining through public policy, the role of the state in development, the place of the market and citizens in the process and analyzing political practice based on these articulations.

To the extent the liberal political theory contributes to the growth of liberal political values in the process of growth of political freedom in the West, it is a worthwhile intellectual practice. Nonetheless, it is caught up in two problematiques. The first is the assumption that liberal democracy, liberal social norms and capitalism are the highest forms of civilization that humanity could possibly attain. The second problem has to do with Western universalism of liberal theories, a tendency which assumes that the trajectory of Western development is the standard universal template for all societies. It neglects contextual elements of each society and how they connect with different cultural backgrounds in determining the trajectory of their development. For instance, if liberal democracy and its defining core activity of elections were to be the solution of the political problems of places like Iraq, Libya, Afghanistan, Congo DR and Nigeria why do we still have continuing major political tensions in these societies? Contributing adequately to development studies in the less developed countries warrants a rise beyond mere elaboration and extension of one ideological project in all societies as though it is the bearer of the one objective truth about the development of societies. Contextual differences of societies must be a necessary part of theory building for each formation. The environment, history, culture and repertoire of knowledge in each society are important points of consideration in specifying the path to their development. The point of considering these factors is the necessity for building authentic knowledge for development.

\section{Authentic Political Theory and its Value for Authentic Development Stud- ies}

Following the dominant subject matter and methodology of Development Studies, it is not difficult to pin down its social commitment. Indeed at the very beginning of political science, it did not make any pretense about its commitment to the defense of liberalism. Much older disciplines like Economics and Sociology were earlier liberal oriented disciplines that actually facilitated the growth of capitalism. Political theory itself was not only within the household of philosophy but also grew from Sociology, History and Anthropology. Dwelling majorly on the work of Herbert Spencer, the contribution of English sociology to political theory was illuminated by Barnes (1921). For instance, Spencer is said to revive the contract doctrine to justify political authority. He also put forward a sociological statement of individualism in which the state was subordinated to the individual. Besides, Spencer correlated the state with society in general, in the attempt to estimate its position and roles in social processes. The liberal principles which are expressed in these contributions did not end as works of sociology or political theory; rather they were carried over to Development Studies which re-echoes the ideological commitments of its constitutive disciplines. More recently, economic discourses revolve around neoliberal economics. Indeed for some scholars creating a civil society is about reducing politics and freeing the market (see Edwards 2014, Fukuyama 2001). The same theoretical inclination bears strongly on a political theme like democracy in which there is a tendency to reduce the concept to a market phenomenon. Saltman, for instance argues that a faulty prevailing notion of democracy in recent times is that it is equal to "liberal capitalism" (see Wells, Slayton, and Scott 2002, 343).

Political development is still viewed as development in line with Western liberal democracy. This notion joins other notions of liberal individualism that are propagated in the dominant Sociology, Economics, Anthropology and other disciplines in constructing the hegemony of liberalism. The contribution of Political theory here is 
the generation of meta-narratives that reinforce liberal assumptions about the political side of structure so as to provide support to the economic and other aspects of society. Thus, the ultimate role of political theory is articulating and defining through public policy, the role of the state in development, the place of the market and citizens in the process and analyzing political practice based on these articulations.

To the extent the liberal political theory contributes to the growth of liberal political values in the process of growth of political freedom in the West, it is a worthwhile intellectual practice. Nonetheless, it is caught up in two problematiques. The first is the assumption that liberal democracy, liberal social norms and capitalism are the highest forms of civilization that humanity could possibly attain. The second problem has to do with Western universalism of liberal theories, a tendency which assumes that the trajectory of Western development is the standard universal template for all societies. It neglects contextual elements of each society and how they connect with different cultural backgrounds in determining the trajectory of their development. For instance, if liberal democracy and its defining core activity of elections were to be the solution of the political problems of places like Iraq, Libya, Afghanistan, Congo DR and Nigeria why do we still have continuing major political tensions in these societies? Contributing adequately to development studies in the less developed countries warrants a rise beyond mere elaboration and extension of one ideological project in all societies as though it is the bearer of the one objective truth about the development of societies. Contextual differences of societies must be a necessary part of theory building for each formation. The environment, history, culture and repertoire of knowledge in each society are important points of consideration in specifying the path to their development. The point of considering these factors is the necessity for building authentic knowledge for development.

In deploying the word authentic we draw from Black skin white masks published 1952 in which Fanon likened the black person to the Jew under anti Semitism in which everything the Jew does is turned against him/her (Fanon 1986). The effect of the psychology of rejection and disparagement among the blacks is the emergence of a framed modal personality that aspires for what does not express his/her original self because the original self is denigrated vis a vis a superior other. In that regard, unless an idea bears an affirmation of the superior other, such idea is not considered good enough. In the manner of Fanon's thesis, African thought about politics and leadership became bleached of authenticity because for each idea to be considered acceptable, it must replicate a form that is known and acceptable within a certain frame of discourse. Thus, democracy must be liberal democracy to be acceptable in spite of the richness of ancient African democratic traditions. Collectivism must pave way for individualism because the latter is the main philosophical anchor of the western development.

In conforming to this kind of intellectual framing, African development scholarship loses authenticity. The confidence to reassert the authentic knowledge that usefully addresses local condition from local knowledge base or evolving ways to blend the local ideas on development with modern approaches which may provide the leeway to the desired change is weak if it ever exists. Besides, being authentic is equally about confidently borrowing a non-indigenous social practice which usefully addresses a development problem, even if it does not agree with dominant ideas.

We liken development planning and organization to steering a ship. Navigating to destination B with a map that led to destination A only makes a crew of sea farers in an endless voyage. Hence an authentic map of the destination that is based on proper knowledge must be established and applied. Political theory spells out the roles of the community and those of its members in the development process. Minimalist liberal political theory for instance, has a limited role for the state in the development process. Apart from interventions for the provision of security, provision of massive physical infrastructure and regulatory framework, the role of the individual and market forces drive development (see Pak 1983). The approximation of the liberal minimalism in economic thought is the neoclassical thesis and the more recent neoliberalism present an aspect of the story of western development theory and this version is yet to work in Africa. The other aspect is the 
structuralist thought in Development economics which sees that the state should play an active interventionist role in driving development. Here, the economic thoughts of John Maynard Keynes come to the fore. Keynes assigned significant functions to the state in actuating economic growth. Specifically he argued that "a somewhat comprehensive socialization of investment will prove the only means of securing an approximation to full employment" (Keynes 1936, 146).

For specific national experiences, on Keynesianism, the Japanese miracle was largely driven by neo-Keynesian practice of state intervention in the economy especially strategic industrial planning and financing to support the private sector for international competitiveness. Basically, Japanese growth was driven by a developmental state model (see Chalmers 1983). Also the economic progress of the fordist era derived in large part from Keynesian formulation that drove economic progress, mostly in the two decades following the end of World War II. Similarly Stiglitz (1996) explained the remarkable success of the eight economies that are part of the East Asia miracle including Hong Kong, Indonesia, Japan, republic of Korea, Malaysia, Singapore, Taiwan and Thailand as a result of high savings rate interacting with high levels of human capital accumulation, in stable market-oriented environment with government's active intervention. In this rendition, Stiglitz presents the state as a complement rather than a replacement for the market. In spite of Stiglitz's points in support of the interventionist state, the same formula failed in most of Africa. In fact, the Berg report (1981) which analysed state failure in Sub-Saharan Africa prescribed the replacement of state intervention with the market and this came in the form of Structural Adjustment Programmes (SAP). The SAP and its embedded neoliberal market regime embedded also failed. Of important note in these changes in national political economies is the role of the state which is an intellectual concern of political theory.

The creation of authentic Political theory that is capable of addressing development questions of non-Western societies that existing theories have attempted in vain to answer requires rigorous intellectual processes that articulate an integral philosophy of development and a clear elabora- tion of how it applies. For instance, the modernization thesis draws its economic philosophy from the body of theories of economics that goes back to the works of the classical economics of Adam Smith, David Richardo, J.B Says; through neoclassical economics of William Jevons, Carl Menger, Leon Walras, Alfred Marshall; to more contemporary economic thoughts of John Maynard Keynes, the neoliberal school. Each of the schools has clearly articulated economic roles for both the community and individuals in society and the principles undergirding such roles. On the political side of liberal development epistemology, liberal Political theories lend reinforcement to its economic thought. For instance, John Locke's liberalism, Jeremy Bentham and James Mill's utilitarianism, Max Weber's theory of the state, power and bureaucracy, Joseph Schumpeter's democratic thought among others have clear specifications of the nature and role of the political structure and their relationship to the individual. Of course the economic thought and political philosophies are historical products of Western material history that links up with their norms, values and social cultures. Hence there is an organic connection between economic, political and sociological thoughts that underpin the modernization approach to development because it tells the story of a particular civilization. In the case of developing societies, the major global institutions that influence development policies nudge these formations towards the market forcescentred approach to modernization.

The one instance in which an African indigenous development model had sought to transcend western modernization trajectory was the policy of African socialism implemented in Tanzania by Julius Nyerere. It was a socialist path to development which integrated fundamental elements of African socio-economic relations with Fabian socialism and some catholic teachings. It was based on the three essentials of freedom, equality and unity. Also, it assumes that equality is the only basis that men will work cooperatively. Regarding the principle of freedom, African socialism assumes that an individual is not served by a society unless it is his. For the principle of unity, it is believed that it is only when a society is unified can its members live and work in peace security 
and wellbeing. These three essentials according to Nyerere are not new to Africa as they have always been part of the traditional social order (Ibhawo and Dibua 2003). While Nyerere had the political will to implement the African socialism, there were hardly rigorously coordinated sociological, economic, political, philosophical and other studies to render the kind of support that liberal social science and philosophy provided to capitalism. Instead, the development praxis offered by African socialism one effort in authentic alternative to western modernization thrived more on sloganeering. Simply put, the theoretical basis was weak. Thus it lacked the intellectual fortress to support continuity in the face of challenges.

An authentic development framework must therefore be designed with a robust research and knowledge production around the assumptions of such a path to development and the popularization of its main ideas, just like mainstream social science does for capitalism. A radical approach of this kind must envision Gramsci's (1971) 'war of position' in which each group seeks to embed and consolidate its social projects over contrary social projects. An important note here is that the sphere of social theorizing is one in which intellectuals function as salesmen of competing ideas and one in which the existing hegemony could either be reinforced or successfully contested in favor of an alternative one (cf. Simon 1991). On this note, the role of liberal political theory is the organization of consent for the hegemony of the dominant political values. Therefore, in expressing political development as cultural secularization and structural differentiation mainstream political theory is playing the role of ideological reproduction by diffusing and embedding the liberal worldview in development. Conversely, the role of an alternative political theory in the search for an authentic framework for African development is the consistent generation of alternative narratives that presents African perspectives in different aspects of development including the knowledge that drives political practice.

Consistency helps in the survival of knowledge and the praxis it supports especially in moments of crisis. For instance the crisis of ujamaa or African socialism resulted in surrender rather than thinking through what was wrong with the model and remedying it. Such surrender failed to consider the history of capitalism and its many crises. For instance, the post World War I depression was resolved after World War II with Keynesian political economy. The recession of the 1960s was another moment of adjustment for capitalism and transition from Keynesian economic thought to neoliberalism. In all the crises of capitalism, liberal theory did not buckle or quit. Instead, as the knowledge base of the prevailing system, it advanced the necessary principles for readjustment of the liberal praxis. At the political level, the growth of fascist authoritarianism in Hitler's Germany and Mussolini's Italy were matters of challenge to development thinkers around politics. Liberal democracy which is already popularized and made the standard benchmark for assessing political practice was handy to constitute a basis for assessing the developments in Germany and Italy. Explanations to each arisen challenge normally seek understanding of the socio-economic and political forces in each historical moment in society. Thus theorizing for authentic development must emanate from constructivist engagement with social realities. Political theory must be rooted in explaining each society for what it is and not comparing differently oriented societies in a manner that makes one society appear like an false imitation of another.

Also regarding consistency, the bane of efforts at producing alternatives to mainstream social science interpretations of society in Africa is the tendency to buckle in the face of crises of political practice. For instance the political economy approach which was reworked by African scholars to reflect the specificities of Africa remains one of the authentic contributions by African intellectuals to the social science. Ake (1983) suggests that the approach critiques liberal thesis and capitalist praxis, accepts important assumptions of the Marxist methodology, but more importantly fills the theoretical gaps of orthodox Marxism and liberal social science. The same approach assumes that reality is characterized by dynamism which arises from the pervasive contradictions of the material base and accepts the relatedness of material existence with social life. Finally, the political economy approach is interdisciplinary. However, this methodological contribution suffered rejec- 
tion and criticism not only by liberal scholars but also by orthodox strands of Marxism. But it is this conceptual framework that clearly lays bare the relationship between economic and political structures and their connection with other aspects of society in explaining developmental outcomes in Africa including those of politics. For instance, themes like economic underdevelopment (see Ake 1981), state, citizenship, power and ethnicity (see Nnoli 1989, Mamdani 2002), civil society, democratization (Ake 1994, Mafeje 1998) have been presented with a clearer grasp of African realities from the political economy viewpoint.

One of the efforts to provide an alternative to liberal political theorizing by Ake (1993) is the unique case of African democracy. In that study, Ake argued that the feasibility of democracy in Africa would depend on the transcendence of the model offered from liberal perspective. The reason is that the structures that support representative liberal democracy may not quite function in Africa as in the West. He noted an important notion of African scholars that political regression in Africa is related to the project that drives political practice and that the course of development is better served by an approach that engages the energy and commitment of the citizens. For Ake, African democracy must reflect the interest of its social base which is located in the citizenry. The rediscovery of the essence of democracy is quite important because liberal democratic thoughts have increasingly removed the idea of peoples' power from the meaning of the concept. Therefore a political theory that serves the course of authentic development is one which promotes the democratization of development. This thought is based on the reason that politics is about struggles to make decisions on how to organize society, set up rules of the game and even to integrate every qualified member of the political community in the decision making process. Development should therefore focus popular agreement and how transformations take place to achieve the most acceptable results for the people. Political Theory can best add value to development studies by constructing its role in knowledge production for value allocation through theorizing the appropriate role of the political community (state) in the process of development in a manner that best addresses the needs of citizens.

In the light of the above, the political theory should make a clear analysis of what exists in terms of the role of the state in development. This analysis must be historically grounded and must reckon with clear weaknesses of the state in development. It should also analyze Africa's encounter with neo-market prescriptions and the outcome of such encounter. While state failure and market failure are both possibilities, the normative aspect of political theory should intervene by clearly deciding what works best for the community in the light of her conditions. While the dominant political theory leaves the largest burden of development to the private citizen and this may actually have worked in capitalist formations where the infrastructure and material incentives that grow capital exists, African oriented political theory needs to engage with African ideas on development and explore their feasibility as pathways to development in the contemporary world. One such idea is the Ubuntu which contrary to liberal individualism, sees the community as the basis of actualizing the individual.

\section{Conclusion}

In exploring the value of Political Theory to Development Studies this paper sees the role of Political Theory in terms of analysis and prescription. The signposts for making the connection between Political Theory and Development Studies are: subject matter, methodology and social commitments of the discipline. Regarding subject matter, the dominant variant of the modernization thesis is found to be central to be the main thrust of its intellectual engagement. The political aspect of the liberal theory specifies the role of the state and individual based on the methodological individualism of the liberal thesis. In spite of Keynesian thesis, modernization majorly project and reflect the individualist assumptions of liberal Sociology, Economics, Political science and Philosophy. The notion of several modernization driven studies is that societies are developed to the extent of their adoption of the developmental pathways of the advanced western capitalist countries.

Regarding methodology, Development studies is observed to be on a course of progress through 
three identifiable phases of multi-disciplinarity, inter-disciplinarity and transdisciplinarity. Authentic theory of development of any aspect of society is expected to build on interdisciplinary and transdisciplinary methodology with a view to evolving an organic unity of the subject areas of development. Such organic unity in knowledge pursuit is expected to be utilized in advancing knowledge about the uniqueness of certain African practices that are relevant to development in the continent.

The social commitment of development studies is found to draw from the mainstream strands of its constitutive discipline. Thus, it has not gone far from the postulations of liberal Economics, Political science and Sociology. Essentially, it is committed to the advancement of liberalism through the popularization of the market pathway to development. Mainstream Political theory is complicit in the current commitment of development studies. But Political theory for African development must be authentic; it must have a constructivist focus on African society, and concentrate on popularizing a knowledge system in which the roles of the political community are spelt out to reflect a model of community that cares and those of citizens who participate actively in the its survival and sustenance.

\section{References}

[1] Acemoglu, Daron, and James A. Robinson. 2013. Why nations fail. London: Profile Books.

[2] Ake, Claude. 1981. The political economy of Africa. London: Longman.

[3] Ake, Claude. 1982. Social science as imperialism. Ibadan: Ibadan University Press.

[4] Ake, Claude. 1983. "The political economy approach: Historical and explanatory notes on Marxian legacy in Africa." Africa Development 8(2): 22-35.

[5] Ake, Claude. 1993. "The unique case of African democracy." International Affairs 69(2): 239-244.

[6] Ake, Claude. 1994. "Democratization of disempowerment in Africa". CASS occasional monograph 1. Lagos: Malthouhe Press Ltd.

[7] Barnes, Harry E. 1921. "Some typical contributions of English Sociology to Political Theory." The American Journal of Sociology 27(33): 289-324.

[8] Chalmers, Johnson. 1983. MITI and the Japanese miracle: the growth of industrial policy 1925-1975. Stanford: Stanford University Press.

[9] Choic, Bernard C., and Anita W. Pak. 2006. "Multidisciplinarity, interdisciplinarity and transdisciplinarity in health research, services, education and policy: Definitions, objectives and evidences of effectiveness." Clinical and Investigative Medicina 29(6): 351-364.
[10] De Soto, Herman. 1993. "The missing ingredient." The Economist 328(7828): 8-10.

[11] De Soto, Herman. 2000. The mystery of capital: Why capitalism triumphs in the West and fails everywhere else. Basic books.

[12] Fangjun, Cao. 2014. "Modernization theory and China's road to modernization." Chinese Studies in History 43(1): 7-16.

[13] Fanon, Frantz. 1986. Black skin white masks. London: Pluto Press.

[14] Frazer, M. 2010. "Three methods of Political theory: historicism, ahistoricism and transhistoricism." Draft for Presentation at the 2010 CPSA.

[15] Friedman, Milton. 1962. Capitalism and freedom. Chicago: The University of Chicago Press.

[16] Fukuyama, Francis. 2001. "Social capital: Civil society and development." Third World Quarterly 22(1): 7-20.

[17] Fukuyama, Francis. 1992. The end of history and the last man. London: Penguin.

[18] Gramsci, Antonio. 1971. Prison notebooks. London: Lawrence and Wishart.

[19] Granato, Jim, Ronald Inglehart, and David Leblang. 1996. "The effects of cultural values on economic development: Theory, hypotheses and some empirical tests." American Journal of Political Science 30(3): 607-631.

[20] Harrison, Lawrence E. 2000. "Promoting progressive cultural change". In Culture Matters, edited by Lawrence E. Harrison. New York: Basic books.

[21] Huntington, Samuel P. 1991. The third wave: Democratisation in the late twentieth century. Norman: University of Oklahoma press.

[22] Ibhawo,Bonny, and Jeremiah I. Dibua. 2003. "Deconstructing Ujamma: the legacy of Julius Nyerere in the quest for social and economic development in Africa." African Journal of Political Science 8(1): 59-83.

[23] Inglehart, Ronald. 2000. "Culture and democracy". In Culture matters, edited by Lawrence E. Harrison and S. Huntington. New York: Basic books.

[24] Keynes, John M. 1926. The end of laissez Faire: the economic consequences of the peace. London: Woolf at The Hogarth Press.

[25] Kwon, O. Yul. 2011. "Does culture matter for economic development in Korea?" The Journal of East Asian Affairs 25(2): 163-182.

[26] Lal, Deepak. 1983. Poverty of development economics. London: The Institute of Economic Affairs.

[27] List, Christian, and Laura Valentin. 2014. "Methodology of Political Theory." In The Oxford Handbook of Philosophical Methodology: 525-550.

[28] Mafeje, Archie. 1998. "Democracy, civil society and governance in Africa". In Proceedings of the Second DPMF Annual Conference on Democracy, Civil Society and Governance in Africa II: 7-10.

[29] Mamdani, Mahmood. 2002. Citizen and subject. Kampala: Fountain publishers.

[30] Nnoli, Okwudiba. 1989. Ethnic Politics in Africa. Ibadan: Vantage Publishers.

[31] Ntibagirirwa, Symphorien. 2009. "Cultural values, economic growth and development." Journal of Business Ethics 84(3): 297-311.

[32] Nwosu, Bernard U. 2012. "Tracks of the third wave: democratic theory, democratization and the dilemma of political succession on Africa." Review of African Political Economy 39(131): 11-25.

[33] Parayil, Govindal. 1990. "Development Studies, a progressive research tradition." Science Studies 2: 47-56. 
[34] Rostow, Walt Whitman, and Walt W. Rostow. 1960. The stages of economic growth: a non communist manifesto. Cambridge: Cambridge University Press.

[35] Schumpeter, Joseph A. 1976. Capitalism, socialism and democracy. London: George Allen and Unwin.

[36] Simon, Roger. 1991. Gramsci's political thought. London: Lawrence and Wishart.

[37] Stiglitz, Joseph E. 1996. "Some lessons from the East Asian miracle." World Bank Research Observer 11(2): 151177.

[38] Stockwell, Edward, and Karen A. Laidlaw. 1981. "The sociology of development." International Review of Modern Sociology 11(1/2): 145-173.

[39] Weber, Max. 1992. Protestant ethics and spirit of capitalism. London: Routeledge.

[40] Wells, Amy Stuart, Julie Slayton, and Scott, Janelle. 2002. "Defining democracy in the neoliberal age: Charter school reform and educational consumption." American Educational Research Journal 39(2): 337-361.

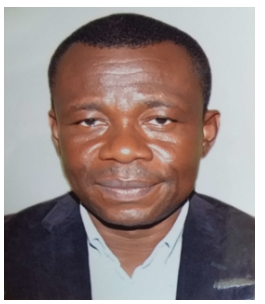

Bernard Nwosu is senior research fellow at the Institute for Development Studies University of Nigeria, Enugu Campus. He also holds a joint parallel position at the Department of Political Science of the same Institution. Ben's doctorate was obtained from The University of Waikato, New Zealand. His research interests are in the areas of democratization and democratic theory, governance, civil society, social change, public policy, sociology of development and conflict. His recent works have appeared in the Review of African Political Economy and Voluntas.

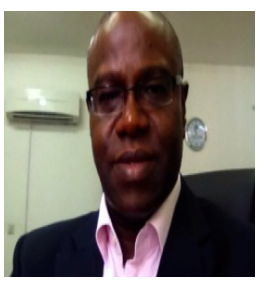

Okechukwu, Ibeanu holds a Ph.D in political science and has been a Professor of Political Science at the University of Nigeria since 2000 . He is presently a Research Professor in Development Studies. Ibeanu has been a visiting scholar at Oxford University, the Woodrow Wilson International Centre in Washington DC, King's College, London. From 2004 to 2010, he served as the Special Rapporteur of the United Nations Human Rights Council on the adverse effects of toxic wastes on the enjoyment of human rights. He has researched on human rights, environment, conflict, development, security, elections and democracy. He was the Chief Technical Adviser to Nigeria's Independent National Electoral Commission, and was a leading member of the team that designed innovations that transformed the conduct of elections in Nigeria from 2011 through 2015. 